\title{
KEBIJAKAN STRUKTUR MODAL, KEBIJAKAN DIVIDEN DAN NILAI PERUSAHAAN BANK BNI
}

\author{
Zainal Arifin H. Masri ${ }^{1}$, Bambang Perkasa Alam ${ }^{2}$ \\ Universitas Indraprasta PGRI e-mail zarifin234@yahoo.com
}

\begin{abstract}
Abstrak
Riset ini mengenai " Kebijakan struktur modal, kebijakan dividen dan nilai perusahaan Bank BNI dengan metode kuantitatif. Laporan keuangan Bank BNI selama berdiri sampai sekarang dijadikan sebagai populasi, penarikan sampel menggunkan teknik kuota sampling dengan hasil laporan keuangan 2001-2020, dianalisis menggunakan regresi linear berganda yang diolah dengan Eviews 9. didapati persamaan regresi linear berganda $\mathrm{EPS}=730,81+1,32 \mathrm{DER}-0,52 \mathrm{DPR} . \quad$ (F-statistik) bernilai0.008971 < 0,05 yang berarti dengan serempak hutang (DER) dan dividen (DPR) mempengaruhi nilai perusahaan (EPS)secara signifikan. Namun demikian secara individual hanya hutanglah yang mempunyai pengaruh signifikanterhadap nilai perusahaan, keadaan ini ditunjukkan prob DER 0,0070 <0,05. Sedangkan dividen tidak memiliki pengaruh kepada nilai perusahan dengan nilai prob DPR 0,7193 > 0,05. Sementara itu hanya 42,57\% hutang dan dividen memberikan kontribusikepada nilai perusahaan sementara sisanya 57,43\% merupakan pengaruh lain.
\end{abstract}

Keyword : Kebijakan struktur modal, kebijakan dividen. Nilai perusahaan, regresi linear berganda

\begin{abstract}
This research is about "Capital structure policy, dividend policy and company value of BNI Bank with quantitative method. The financial statements of Bank BNI during its existence until now have been used as the population, sampling using the quota sampling technique with the results of the 2001-2020 financial statements, analyzed using multiple linear regression processed with Eviews 9. It was found that the multiple linear regression equation EPS $=730.81+1,32 \mathrm{DER}-0.52 \mathrm{DPR} .($ F-statistics $)$ is worth $0.008971<0.05$, which means simultaneously debt (DER) and dividends (DPR) significantly affect firm value (EPS). However, individually, only debt has a significant effect on firm value, this situation is indicated by the prob DER of $0.0070<0.05$. While dividends have no effect on the value of the company with a prob DPR value of $0.7193>0.05$. Meanwhile, only $42.57 \%$ of debt and dividends contributed to the firm's value while the remaining $57.43 \%$ were other influences.
\end{abstract}

Keyword : Capital structure policy, dividend policy. firm value, multiple linear regression

\section{A. PENDAHULUAN}

Asalnya dana-dana perusahaan didapatimelalui modal sendiri maupun utang. Modal ekuiti diperoleh melalui setoran tunai para pemegang saham atau menjual kepemilikan perusahaan dengan menjual saham kepada calon pemegang saham atau investor. Utang diperolehdari pinjaman/kredit atau menjual obligasi (surat pernyataan utang).Baik modal 
sendiri maupun utang memiliki kelebihan dan kekurangannya masing-masing.

Menggunakan modal sendiri, pemilik harus membagi kepemilikannya atas perusahaan kepada pemegang saham lainnya, dan tidak ada kewajiban membayar bunga hutang dan hutang pokoknya.Sedangkan

menggunakanhutang, pemilik tidak perlu membagi kekuasaannya atas perusahaan kepada orang lain, tetapi punya kewajiban membayar bunga hutang dan pokok hutangnya.

Perusahaan harus dapat menentukan komposisi yang sesuaitotalhutang dan modal ekuiti sebagai modal perusahaan.Kebijakan struktur modal merupakan kebijakan untuk menentukan komposisi modal perusahaan. Apakah seluruhnya modal sendiri, atau seluruhnya hutang, atau gabungan dari modal sendiri dan hutang dengan perbandingan tertentu.

Dividen diartikan sebagai bagian keuntungan bersih yangdialokasikan kepada para stockholder perusahaan.Pembagian dividen penting untuk menarik ketertarikanpemilik modal membeli saham perseroan, meskipun investor lebih suka pada capital gain (harga jual saham dikurang harga beli saham) daripada dividen. Di sisi lain, semakin rendah dividen yang dialokasikan, makin rendah nilai perseroan.

Nilai perseroan sering dihubungkan dengan price market stock - makin naik harga pasar saham, makin naik nilai perseroan. Selanjutnya makin murah harga pasar saham, makin rendah nilai perusahaan. Dalam kaitan membeli saham, investor akan melihat berbagai indikator untuk menentukan layak tidaknya saham itu dibeli. Salah satu indikator adalah Earning Per Share (EPS). EPS dipergunakan untuk menganaltingkat nilai suatu saham mahal atau murah.Nilai tersebut diperoleh dari pembagian keuntungan bersih perusahaan dibagi total lembar saham perusahaan.
Mengacu kepada penjabaran, maka dapat diperoleh beberapa masalah yang mau dijawab berdasarkan penelitian ini, yaitu : (1) asal modal perusahaan bisa berupa modal ekuiti dan atau hutang, (2) menentukan biaya modal yang minimal baik modal ekuitiataupun modal hutang, (3) struktur modal menentukan nilai perusahaan, (4) pembagian deviden kepada stockholderakan menaikkan nilai pasar saham perusahaan, (5) menetapkannilai deviden yang akan disalurkan kepada para stockholder, (6) tinggi rendahnya nilai pasar saham perusahaan akan menentukan nilai perusahaan, (7) pihak Manajemen dapat menentukan kebijakan pendanaan, kebijakan deviden untuk menaikkan nilai perusahaan

Didasarkan kepada identifikasi maka perlu dibuatbatasanyaitu : (1) menentukan komposisi/struktur modal. Apakah seluruhnya dari modal ekuiti atau hutang atau setengah modal ekuiti dan sisanya hutang, (2)menentukan apakah perusahaan akan membagi deviden dan berapa besarnya, (3) menentukan kebijakan investasi dan kebijakan deviden secara serempak dalam rangka menaikkan nilai perseroan.

\section{B. TINJAUAN PUSTAKA}

\section{Kebijakan Struktur Modal}

Keputusan investasi berkenaan dengan keputusan perseroansaat mencari modal untuk memenuhi biaya investasi dan menetapkanpembagian sumber modal (Kumar et al, 2012). Komposisi sumber pendanaan merupakan perbandingan antara utang perusahaan dengan modal sendiri yang dimiliki perusahaan.Komposisi sumber pendanaan sering disebut juga sebagai struktur modal.

Pengembangan Teori struktur modal oleh ahli-ahli terutama dimanfaatkan untuk mendapati apakah perseroan dapat meningkatkan kesejahteraanstockholder (nilai perusahaan) berdasarkan struktur modal yang berubah.Capital 
structuremerupakan modal milik sendiri dibandingkan dengan hutang.Weston dan Copeland (2001) mengatakan bahwa Capital structureadalah pembiayaan tetapdari lingkuphutang, saham preferen dan modal dari stockholder.

Sementara itu Fabozzi dan Peterson (2003) berpendapat bahwa capital structureyaitu kumpulan dari pinjaman dan equity modal yang dipergunakan untuk membiayai kegiatan perseroan. Sedangkan Keown et al (2001) menyatakan bahwa capital structure yaitukumpulandari sumber dana jangka panjang yang dipergunakan oleh perseroan. Margaretha (2004) mengemukakan struktur modal membuktikan pembiayaan tetap perseroanyaituhutang dan modal ekuiti.

Terdapat teori-teoriyang berhubungan denganCapital structure yang disajikan oleh beberapa ahli,yaitu :

1. Teori Pendekatan tradisional. Pada teori ini Capital structuremempunyai pengaruh kepada nilai perusahaan. Capital structuredapat

inkonsistensupayabisa diperoleh nilai perseroal yang terbaik (Sutrisno, 2014, Harjito dan Martono, 2013)

2. Teori PendekatanModigliani dan Miller (Teori MM, 1958). Teori MM terbagi 2, yaitu :

a. Teori MM Tanpa Pajak. MM mempunyai pendapat bahwa Capital structuretidak sesuai atau tidak memiliki pengaruhterhadap nilai perseroan. MM (dalam Brigham dan Houston, 2014) membentuk teori berlandaskan beberapaanggapan: non pajak, nonbeban agensi, data yang proporsional antara pemberi dana dan perseroan, pemberi danabisa meminjam dengan jenjang bunga yang mirip dengan perseroan, non bebanpailit, hutnag tidak memepengaruhi Earning Before Interest and Tax (EBIT), peminjammerupakanprice

takers (penerima harga), jika terjadi pailit, harta perseroan dijualkan pada harga pasar.

b. Teori MM dengan Pajak. MM menyadari adalah tidak secara nyatakalau tidak memasukkan faktor pajak. MM kemudian menuangkanfaktor pajak kedalam teorinya. Hutang dapat dipergunakan untuk meminimalkan pajak, karena interst mengurangi keuntungan bersih yang diperoleh perusahaan, selanjutnyadapat mengurangi pajak yang wajib dibayarkan

3. Trade-off theory. Trade-off theory sebagaimana dijabarkan oleh Myers (2001), perseroann akan meminjam hinggakepada jenjanghutang terspesifik, dimana pengiritan pajak dari tambahan pinjamanserupa dengan bebankesussahan keuangan/biaya pilit. Mengacu pada Brigham dan Houston (2011) trade-off theory pada Capital structure merupakanmenyelaraskankegunaan dan pengorbanan yang munculakibat terbitnyapemanfaatanhutang. Jika kegunaan lebih banyak, menambahhutang masih diperbolehkan. Namun bila pemanfaatan utang sudah lebih tinggi, maka menambah hutang sudah tidak diperkenankan.

\section{Kebijakan Deviden}

Dividen yaitu besarnya pembagian keuntungan yang dialokasikan oleh perseroan kepada para stockholder. Deviden policy merupakan suatu strategi perseroan dalam menetapkan besarnya keuntungan yang akandialokasikan sebagai deviden. Beberapa konseptentang 
kebijakan deviden yang diutarakan oleh beberapa ahli antara lain yaitu:

1. Teori Dividen Non Relevan berdasarkan Modigliani dan Miller.

Modigliani dan Miller (1963) memiliki pendapat, ukuran perseroan tidak ditetapkan dengan ukuran besar ataupun kecil tingkat keuntungan yang ditukarkan pada stockholder berbentuk cash atau DPR (Dividen Payout Ratio), namun ditetapkan oleh keuntungan bersih sebelum pajak atau EBIT serta tingkat ganjaran perseroan. Berdasarkan pendapat tersebut maka Modigliani dan Miller mendefinisikan, dividen tidaklah sesuai. pendapat ini dilandaskan kepada dugaan-dugaansesensial yang kurang kuat seperti: capital market sempurna yaituseluruhpendana rasional, non beban emisi saham baru apabila perseroan mencetak saham yang baru, non pajak. Kebijakan pendanaan perseroaan tetap. Sedangkan pada penerapannya: market capital sempurna jarang didapati, biaya emisi saham baru sudah dipastikan ada, pajak juga sudah dipastikan ada, kebijakan pendanaan perseroanmustahilpermanen.

2. Teori Dividen yang Relevan (The Bird in the Hand) Gordon dan Lintner.

Mengacu pada teori ini,Cost of equityperseroa akan meningkatapabilaangkakeuntungan yang ditukarkan kepada stockholder dalam bentuk Cash atau DPR tidak tinggi, investor lebih berkenanmendapatkan dividen ketimbang mendapatkan modal (Capital Gains). Pemberi danaberpendapat bahwaprofit dividen (dividend yield) lebih nyata dari pada Profit capital gains (capital gains yield).
Berdasarkanpandanganpemberi dana, Cost of equity dari profit ditahan merupakan tingkat profit yang ditetapkan pemberi dana pada saham. Profit ditahan yaituprofit dari dividen (dividend yield ) ditambahkanprofit dari keuntungan modal ( capital gains yield). Berdasarkan sisi Modigliani dan Miller ada anggapanpendapat Gordon dan Lintner ini sebuah kekhilafan ( M memakaikonsep " The Bierd in the hand Fallacy "). Merujuk pada pendapat MM, pada kesudahannya pemberi dana akan berulang penanaman modal dividen yang diperolehnya kepada perseroan yang mirip atau perseroan yang mempunyai ganjaran serupa.

3. Teori Perbedaan Pajak (Tax Differential Theory) dLitzenberger dan Ramaswamy.

Mengacu pada konsep initerdapatnya pajak atas laba dividen dan keuntugan modal, para pemberi dana lebih berkenan kepadakeuntungan

modalpenyebabnya disebabkan oleh diperolehnyapemunduran pembayaran pajak. Pemberi modal menuntut jenjang profit yang lebih besar pada saham yang menghasilkan dividend yield tinggi, imbal keuntungan modal yang relatif kecildibandingkan saham dengan dividend yield kecil, imbal keuntungan modaltinggi. Apabila pajak dividen berlebihtinggi dari tax atas keuntungan modal, ketidaksamaan ini nampak makin nyata. apabila manajemen mempercayai bahwa teori Dividen kurangsesuai dari MM adalah betul, hasilnya perseroan tidak usahmenghiraukanseberapa banyak dividen yang wajib dibagikan, namun apabila mereka meyakini teori Dividen sesuai, wajiblah 
merekamembandingkantotalprofits esudah pajak atau EAT (Earnig After Tax) kedalam wujud dividen. Apabila jika management lebih meyakinikonsep perbedaan pajak (Tax Differential Theory), makawajibtidak

membagikanseluruh EAT atau $\mathrm{DPR}=0 \%$. Oleh karena itu tiga teori yang sudahdi ulas mewakili kutub - kutub ekstrim dari konsep tentang kebijakan dividen. namun test secara pengalaman belum menghasilkan jawaban yang sesuai dengan tentang konsepyang terbetul.

4. Teori Signaling Hypothesis.

\section{Berdasarkan}

pengalamanjikaterdapatdeviden naik, maka selalu diiringi dengan harga saham yang naik pula.Begitu juga apabila dividen turun secara kebiasaannya mengakibatkan menurunnya harga saham. Gejala inidiibaratkan sebagai alasan bahwa Investor-investor lebih menyenangi dividen dari pada keuntungan modal. namun MM memiliki pendapat bahwa terjadinya divide naik diatas lazimnya menjadi suatu pertanda kepada investor-investor bahwa manajemen perseroanmemprediksi suatu penerimaan yang bagus tentang dividen padaera yang akan datang.kebalikannya, suatu kemerosotan dividen atau dividen yang naik dibawah peningkatan normal (biasanya) dipercayaipemberi dana bahwa perseroanpasti menempuh era yang berat tentang dividen diwaktu akan datang. sebagaimana halnya teori dividen lainnya, teori ini juga susah dibuktikan secara lapangan. Merupakan kenyataan bahwa pergerakan dividen memiliki beberapa berita.namunrumitdinyatakan apakah naik dan turunnya price sesudahmunculnyanaik dan turunnya dividen seyogianya diakibatkan oleh akibat tanda atau disebabkan karena akibat tanda dan pengkhususan terhadap dividen.

5. Teori Clientele Effect.

Teori ini berpendapatkumpulan (clientele) stockholder yang tidak sama akan mempunyaipengutamaan yang lainkepada kebijakan dividen perseroan. Sekumpulan stockholder yang memerlukan pendapatan pada masa sekarang lebih menyenangi suatu tingkatkeuntungan yang diberikan atau DPR (Dividend Payout Ratio) yang besar. Berbanding terbalik dengansekumpulan pemegang saham yang kurangmemerlukan uang sekarang ini lebih menyukai apabila perseroan menunda sebagian besar keuntungan bersih perseroan. Apabila terdapat keridaksamaan pajak bagi perorangan (umpamanya orang tua renta dikenai pajak yang lebih rendah) maka stockholder yang dikenakan pajak naik lebih menyenangi perolehan modal (capital gains) karena dapat memperlama pembayaran pajak. sekumpulan ini lebih sukaapabila pererseroanmemberikan dividen yang rendah. berbanding terbalik dengan kelompok stockholder yang dikenakan pajak relatif kecilpasti lebih mengarahmenyenangi dividen yang tinggi.Bukti lapanganmenghasilkan bahwa terdapatakibat dari Clientele ini. Namun berdasarkan MM hal ini tidaklahmemperlihatkan bahwa dividen kecil lebih bagus, maupunjuga kebaikannya. Kebijakan dividen merupakan keputusan apakah keuntungan yang didapat perseroan akan 
dialokasikan kepada stockholder sebagai dividen atau akan ditunda dalam bentuk profittidak dibagiuntuk pembiayaan penanaman modal di eramendatang. jika perseroanmenunjuk untuk memberikankeuntungan sebagai dividen, otomatis akan berkuranglahkeuntungan yang dibelum dibagi dan berdampak total sumber dana intern atau internal financing berkurang. Lain halnyaapabila perseroan memilih untuk tidak membagikeuntungan yang dihasilkan, maka kekuatanpembuatan dana intern akan semakin tinggi. Oleh karena itu, kebijakan dividen wajib diselidiki dalam hubungannya dengan ketetapan pembelanjaan atau ketetapan struktur modal secara total.

Kebijakan Dividen ada beberapa macam, antara lain :

a. Kebijakan dividen dengan presentase tidak berubah pembayaran dividen cash (constant - payout - ratio divident policy) yaitu kebijakan dividen yang dilandaskan dengan presentase tertentu dari penerimaan.

b. Kebijakan dividen biasa atau stabil (reguler dividen policy) yaitu kebijakan dividen yang dilandaskan atas pemberian dividen dengan rupiah yang konstan pada satu masa.

c. Kebijakan dividen rendah plus ekstra (low - regular - an extra dividend policy). Berdasarkan kebijakan ini perseroanmemberikan dividen cash secara berkesinambungantiap periode dalam angka yang konstan dan kecil, apabilaprofit perseroan periodetertentu sangat bagus maka totalpemberiankonstanitu akan ditambahkanpemberian dividen lebih.

d. Kebijakan dividen yang elastis. Perseroanmenentukanukuran dividen payout ratio tiap tahun disingkronkan dengan posisi keuangan dan kebijakan keuangan.

e. Kebijakan dividen residu. Kebijakan ini untuk menghambatkeuntungan untuk membelanjai momenpendanaan yang mencukupikualifikasi. Dividen ini untuk menghambatmomenpendanaankeun tungan untuk membelanjai yang mencukupikualifikasi. Dividen akan diberikan, jika ada keuntungansesudahsemua

kesempatan pendanaan yang memenuhi kualifikasi dibelanjai tersisa.

Bentuk-bentuk dari Kebijakan Dividen yaitu :

a. Dividen Saham (Stock Dividend). Stock dividen yaitu dividen dalam wujud saham kepada Stockholder.

b. Pemecahan Saham (Stock Splits). Stock splits yaitumutasi nilai nominal per lembar saham dan mutasi jumlah saham yang beredar.berdasarkanpenyebab pemecahnya. Dibagi jadi dua jenis, yaitu pemecahan nilai nominal saham dalam nilai nominal yang lebih rendah (split up) dan peningkatan nilai nominal saham (split down).

c. Pembelian Kembali Saham (Repurchase of Stock). Perseroandiharuskan melaksanakan pembelian ulang saham perseroandisebabkan

perseroanmempunyai kas yang berlebih, dan tidak ada kesempatan pendanaan yang menguntungkan. argumen lain kemungkinandisebabkan perseroan akan melaksanakanmerger dengan perseroan lain. 


\section{Nilai Perusahaan}

Nilai perusahaanyaitupandanganpemberi modal terhadap perseroan yang selalu dihubungkan dengan harga saham.Oleh sebab itu, padateorifinansial pasar modal harga saham di market dikatakan konsep nilai perusahaan (Harmono, 2017). Apabila harga saham meninggi maka nilai perseroan juga akan meninggi.

Tujuan manajemen perseroanyaitumengoptimalkan nilai asset para stockholder perseroan (Harmono, 2017).Nilai perusahaan bisa diukur berdasarkan nilai harga saham perseroan di market keuangan. Apabila harga saham meninggi maka nilai perseroan juga akan meninggi. Menurut Harmono (2017) parameter yang menularkan nilai perseroanbisa dilaksanakan memakai beberapa cara, antara lain:

1. Price Book Value (PBV). PBV yaitu salah satu parameter yang dipertimbangkan pemilik dana dalam membeli saham. PBV bisa dihitung dengan rumus :

$$
\text { PBV }=\text { Harga pasar saham }
$$

2. Price Earning Ratio (PER). PER bisa dihitung menggunakan rumus : Harga pasar saham

$\mathrm{PER}=$

Laba per saham

3. Earning Per Share (EPS). EPS bisa dihitung menggunakan rumus : Laba Bersih

\section{EPS =}

\section{Total Saham}

Struktur modalyaituequity modal dibagi denganmodal asing. Pada keadaan ini modal asing merupakanpinjaman jangka pendek ataupun pinjaman jangka panjang. Lain halnya dengan modal sendiri terdiri darikeuntungan ditahan dan kepemilikan perseroan. perbandingan modal akan mempengaruhi nilai perseroan

Dividen merupakan bagian profit yang dibagikan kepada stockholder. Dividen akan mempengaruhi harga saham perseroan di market keuangan. Nilai perseroandidasrkan oleh ukuran harga saham perseroan.Harga saham akan tinggi maka diikuti dengan nilai perusahaan yang tinggi pula.

Nilai perusahaan merupakan cara pandangpemilik danakepada perseroan yang selalu dihubungkan dengan harga saham. Oleh sebab itu, padateori keuangan pasar modal harga saham dipasar disebut sebagai konsep nilai perseroan (Harmono, 2017). Harga saham akan tinggi maka diikuti dengan nilai perusahaan yang tinggi pula.

Berlandaskan pemikiran di atas disusunlah suatu kerangka pemikiran sebagai berikut :

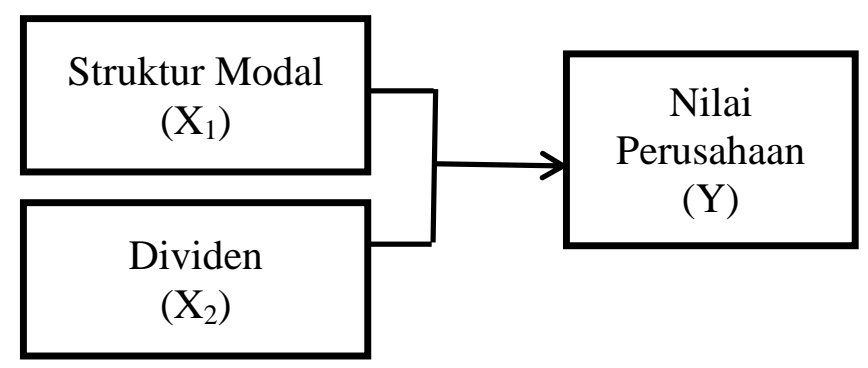

Gambar 1. Kerangka Pemikiran

Adapun model matematika dari kerangka pikir adalah : $\mathrm{Y}=\mathrm{f}\left(\mathrm{X}_{1}, \mathrm{X}_{2}\right)$, sehingga mpdel ekonometrikanya menjadi : $\mathrm{Y}=\alpha+$ $\beta_{1} X_{1}+\beta_{2} X_{2}$

Hipotesis merupakan jawaban sementara atas masalah yang sedang diteliti. Hipotesis penelitian ini adalah :

$\mathrm{H}_{\mathrm{o} 1}$ : tidak ada pengaruh yang signifikan secara simultan struktur modal dan dividen terhadap nilai perusahaan

$\mathrm{H}_{02}$ : tidak ada pengaruh yang signifikan struktur modal terhadap nilai perusahaan

$\mathrm{H}_{03}$ : tidak ada pengaruh yang signifikan dividen terhadap nilai perusahaan

\section{METODE PENELITIAN}

\section{Populasi, Sampel dan Sampling}


Popoulasi dalam riset ini yaitu laporan keuangan Bank BNI mulai berdiri sampai sekarang.Sedangkan sampelnya adalah laporan keuanganbank BNI tahun 20002020.Teknik pengambilan sampel atau sampling adalah non probability sampling dengan jenis sampling kuota.

\section{Variabel penelitian}

Untuk memudahkan penelitian variabelvariabel penelitian perlu didefinisikan baik secara konsepsional maupun secara operasinal berikut skala pengukuran.Definisi variable-variabel penelitian tersebut yaitu:

Tabel 2. Definisi Operasional Variabel Penelitian

\begin{tabular}{|c|c|c|c|c|}
\hline $\mathbf{N}$ & $\begin{array}{c}\text { Na } \\
\text { ma } \\
\text { Vari } \\
\text { abel }\end{array}$ & $\begin{array}{c}\text { Definisi } \\
\text { Konsept } \\
\text { ional }\end{array}$ & $\begin{array}{c}\text { Definisi } \\
\text { Operasi } \\
\text { onal }\end{array}$ & $\begin{array}{c}\text { Skala } \\
\text { Pengukur } \\
\text { an }\end{array}$ \\
\hline 1 & $\begin{array}{l}\text { Stru } \\
\text { ktur } \\
\text { Mod } \\
\text { al }\end{array}$ & $\begin{array}{l}\text { Perbandi } \\
\text { ngan/ko } \\
\text { mpo-sisi } \\
\text { pinjaman } \\
\text { dengan } \\
\text { modal } \\
\text { sendiri }\end{array}$ & $\begin{array}{l}\text { Debt } \\
\text { Equity } \\
\text { Ratio } \\
\text { (DER), } \\
\text { dihitung } \\
\text { dengan } \\
\text { rumus : } \\
\text { Hutang } \\
\text { DER = -- } \\
\text {--------- } \\
\text { Equity }\end{array}$ & $\begin{array}{l}\text { Rasio } \\
\text { dalam } \\
\text { persen }(\%)\end{array}$ \\
\hline 2 & $\begin{array}{l}\text { Divi } \\
\text { den }\end{array}$ & $\begin{array}{l}\text { Bagian } \\
\text { laba } \\
\text { yang } \\
\text { akan } \\
\text { dialokasi } \\
\text { kan pada } \\
\text { para } \\
\text { Stockhol } \\
\text { der }\end{array}$ & $\begin{array}{l}\text { Dividen } \\
\text { Payout } \\
\text { Ratio } \\
\text { (DPR) } \\
\text { adalah } \\
\text { perbandi } \\
\text { ngan } \\
\text { dividen } \\
\text { dengan } \\
\text { profit } \\
\text { bersih, } \\
\text { dihitung } \\
\text { dengan } \\
\text { rumus : }\end{array}$ & $\begin{array}{l}\text { Rasio } \\
\text { dalam } \\
\text { persen }(\%)\end{array}$ \\
\hline & & & Dividen & \\
\hline
\end{tabular}

\begin{tabular}{|c|c|c|c|c|}
\hline & & & $\begin{array}{l}\text { DPR = -- } \\
--- \\
\text { Laba } \\
\text { Bersih }\end{array}$ & \\
\hline 3 & $\begin{array}{l}\text { Nilai } \\
\text { Peru } \\
\text { saha } \\
\text { an }\end{array}$ & $\begin{array}{l}\text { Nilai } \\
\text { perusaha } \\
\text { anyaitup } \\
\text { andanga } \\
\mathrm{n} \\
\text { pemberi } \\
\text { modal } \\
\text { terhadap } \\
\text { perseroa } \\
\text { n yang } \\
\text { selalu } \\
\text { dihubung } \\
\text { kan } \\
\text { dengan } \\
\text { harga } \\
\text { saham }\end{array}$ & $\begin{array}{l}\text { Earning } \\
\text { Per } \\
\text { Share } \\
\text { (EPS)ada } \\
\text { lah } \\
\text { memban } \\
\text { dingkan } \\
\text { antara } \\
\text { dividen } \\
\text { dengan } \\
\text { profit } \\
\text { bersih, } \\
\text { dihitung } \\
\text { dengan } \\
\text { rumus : } \\
\text { Laba } \\
\text { Bersih } \\
\text { EPS = --- } \\
\text {---------- } \\
\text {-- } \\
\text { Jml } \\
\text { Saham }\end{array}$ & $\begin{array}{l}\text { Rasio } \\
\text { dalam } \\
\text { Rp/Saham }\end{array}$ \\
\hline
\end{tabular}

\section{Teknik analisis data}

Riset ini berjenis penelitian kuantitatif.Metode kuantitatif dipergunakan untuk menjelaskan secara statistik/angka hubungan dan pengaruhcapital structure, dividen terhadap nilai perseroan. Metode kuantitatif yang dilakukan terdiri dari :

a. Pengujian asumsi klasik:

1. Uji Multikolinearitas. Uji ini memiliki tujuan gunamengukur model regresi apakah didapati adanya hubungan diantara variabel tidak terikat. Oleh karenanya dalam mengetahui terdapat atau tidak terdapatnya multikolinearitas pada model regresi bisa 
diamatiberdasarkan nilai Tolerance dan variance inflation factor (VIF). Apabila angka VIF kecilsepuluh dan Tolerance lebih besar 0,05, jadi model regresi bebas dari multikolinearitas

2. Uji Korelasi LM Test. Pengujian dilaksanakan

untukmendapatiterdapat atau tidak terdapatnya hubungan antar variabel independen, dengan persyaratan apabila Prob ChiSquare $>0,05$ berarti korelasi antar variabel tidak terjadi.

3. Uji Heteroskedastisitas. pengujian ini mempunyai tujuanagar dapatmengukur model regresi apakah telahada ketidaksamaan varian dari residual satu observasi ke observasilainnya. Metode biasa yang digunakan yaitu uji White, dengan persyaratan Prob ChiSquare (obs R Squared) minimum 0,05 disimpulkan tidak ada problem heteroskedastisitas.

4. Uji Normalitas. Pengujian ini mempunyai tujuan gunamengukur nilairesidual yang sudahterpatok pada model regresiapakah terdistribusi secara normal atau tidak. Jika Prob di atas 0,05 disimpulkan data terdistribusi normal.

b. Analisis Regresi Linear Berganda. Digunakan untuk memahami pengaruh variabel tidak terikat terhadap variabel ter ikat.Variabel-variabel bebasnya adalah capital structure dan dividen. Sedangkan variabel terikatnya adalah Nilai Perusahaan. Sedangkan model regresi linear bergandanya adalah :Y $=\alpha+\beta_{1} \mathbf{X}_{1}+\boldsymbol{\beta}_{2} \mathbf{X}_{2}$

Uji regresi linear berganda mencakup :

i. Uji Signifikansi Simultan (Uji F). Uji ini dilaksanakan untuk mendapatkan hasil pengaruh variabel-variabel bebas secara simultan terhadap variabel terikat. Untuk mengetahui signifikansi pengaruh tersebut digunakan kriteria : $F_{\text {hitung }}>F_{\text {tabel }}$ berarti berpengaruh

ii. Uji Signifikansi Individual (Uji t). Uji ini dilaksanakan untuk mendapatkan hasil pengaruh variabel-variabel bebas secara masing-masing terhadap variabel terikat. Uji ini dilaksanakan dengan melakukan uji regresi linear single equation dari masing-masing variable bebas.Untuk mengetahui signifikansi pengaruh tersebut digunakan kriteria : $t_{\text {hitung }}>t_{\text {tabel }}$ berarti berpengaruh

iii. Keofisien Determinasi $\left(\mathrm{R}^{2}\right)$. Koefisien determinasi untuk mengamatiukuran kemampuan variabel bebas secara serempak memberikan penjelasan terhadap variabel terikat. Nilai $\mathrm{R}^{2}$ berkisar antara 0 sampai dengan $1(0 \leq$ $\left.\mathrm{R}^{2} \leq 1\right)$

\section{HASIL PENELITIAN DAN PEMBAHASAN}

\section{Hasil Penelitian}

Analisis Deskriptif

Data Debt Equity Ratiao (DER), Dividen

Payout Ratio (DPR dan Earning Per Share

(EPS) Bank BNI 2001 - 2020 dapat dilihat pada grafik ini:

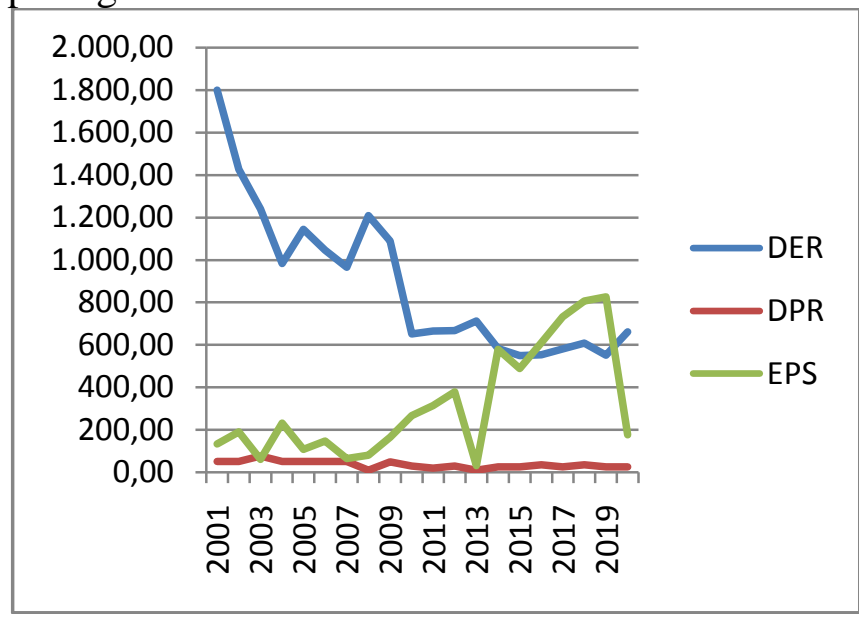

\section{Gambar 2. DER, DPR dan EPS Bank BNI 2001=2020}


Data riil yang diperoleh diolah dengan menggunakan MS Excel diperoleh hasil sebagaimana tampak pada tabel berikut:

\section{Tabel 1. DER, DPR dan EPS banl BNI} 2001-2020

\begin{tabular}{|c|r|c|c|}
\hline NO & DER $(\%)$ & DPR & EPS \\
\hline 2001 & $1,798.57$ & 50.00 & 132 \\
\hline 2002 & $1,426.13$ & 50.00 & 189 \\
\hline 2003 & $1,238.64$ & 75.01 & 60 \\
\hline 2004 & 981.70 & 50.00 & 231 \\
\hline 2005 & $1,142.42$ & 50.00 & 106 \\
\hline 2006 & $1,045.00$ & 50.00 & 145 \\
\hline 2007 & 964.54 & 50.00 & 64 \\
\hline 2008 & $1,207.17$ & 10.00 & 80 \\
\hline 2009 & $1,088.18$ & 47.48 & 163 \\
\hline 2010 & 650.46 & $\mathbf{3 0 . 0 0}$ & 266 \\
\hline 2011 & 663.83 & $\mathbf{2 0 . 0 0}$ & 312 \\
\hline 2012 & 665.77 & $\mathbf{3 0 . 0 0}$ & 378 \\
\hline 2013 & 710.89 & $\mathbf{1 0 . 0 0}$ & 30 \\
\hline 2014 & 582.68 & $\mathbf{2 5 . 0 0}$ & 578 \\
\hline 2015 & 548.40 & $\mathbf{2 5 . 0 0}$ & 487 \\
\hline 2016 & 552.02 & $\mathbf{3 5 . 0 0}$ & 610 \\
\hline 2017 & 578.86 & $\mathbf{2 5 . 0 0}$ & 730 \\
\hline 2018 & 608.15 & $\mathbf{3 5 . 0 0}$ & 805 \\
\hline 2019 & 550.77 & $\mathbf{2 5 . 0 0}$ & 825 \\
\hline 2020 & 661.15 & $\mathbf{2 5 . 0 0}$ & 176 \\
\hline N & 20 & 20 & 20 \\
\hline 又 & 883.27 & 35.87 & 318.35 \\
\hline Max & $1,798.57$ & 75.01 & 825.00 \\
\hline Min & 548.40 & 10.00 & 30.00 \\
\hline
\end{tabular}

Sumber : Laporan Tahunan Bank BNI 2001-2020, data diolah denganMS Excell

Berdasarkan tabel 1 nilai maksimum untuk variable DER,DPR dan EPS masingmasing adalah $1.798,57 \%, 75,01 \%$ dan 825. Nilai minimumnya diperoleh masingmasing adalah $548,40 \%, 10 \%$ dan 30 . Sedangkan nilai rata-ratanya adalah $874,10 \%$, 31, dan 346, 15 .

\section{Analisis Kuantitatif}

\section{Persamaan Regresi Linear Berganda}

Didasarkan pada keluaran olahan data dengan Eviews didapatkan hasil sebagai berikut EPS $=$ 730,81 + 1,32 DER $-\mathbf{0 , 5 2}$ DPR. Hal ini menunjukkan bila tidak ada pembagian dividend $(\mathrm{DPR}=0)$ dan tidak ada hutang (DER = 0) maka nilai perusahaan (EPS) sama dengan 730,81. Jika DPR naik/turun 1 satuan, maka EPS akan turun/naik sebesar 0,52 satuan. Jika DER naik/turun 1 satuan, maka EPS akan naik/turun 1,32 satuan

\section{Uji F-statistik.}

Nilai probabilitas (F-statistik) bernilai $0,008971<0,05$ yang menunjukkan bahwa DPR dan DER berpengaruh signifikan secara serempak terhadap EPS.

\section{Uji t-statistik.}

Nilai probabilitas (t-DPR) $0,0070<$ 0,05, yang berrarti DPR berpengaruh signifikan terhadap EPS. Sedangkan nilai probabilitas (t-DER) senilai 0,7193>0,05, yang berarti DER tidak berpengaruh terhadap EPS secara signifikan.

\section{Uji Koefisien Determinasi.}

Nilai $\mathrm{R}^{2} \quad(\mathrm{R}$ squared) bernilai 0,425677. Yang dapat diterjemahkan bahwa kontribusi DPR dan DER dalam mempengaruhi EPS sebasar 42,57\%. Sisanya sebesar $57,43 \%$ merupakan faktor lain di luar model.

\section{Uji Asumsi Klasuk}

\section{Uji Normalitas}

Berdasarkan hasil pengolahan data diperoleh nilai probabilitas bernilai $0,630686>0,05$ yang mengandung makna data berdistribusi secara normal.

\section{Uji Multikolinearitas VIF}

Berdasarkan hasil pengolahan data nilai Centered VIP baik untuk DPR maupun 
untuk DER $<10$, yang berarti data tidak adakolinearitas antara variabele bebas.

\section{Uji heteroskedastisitas}

Berdasarkan hasil pengolahan data diperoleh nilai Probabilitas (F-statistik) bernilai $0,537763>0,05$ bermakna data tidak terjadi heteroskedastisitas.

\section{E. KESIMPULAN DAN SARAN}

\section{Kesimpulan}

Kesimpulan dirangkum dari hasil pembahasan yang menyangkut riset yang dilakukan sebagai berikut, yaitu : persamaan regresi yang diperoleh adalah EPS $=730,81+1,32$ DER $-0,52$ DPR.Persamaan ini mengandung pengertian jika hutang bank BNI $=0$ dan tidak ada pembagian dividen maka nilai perusahaan $=730,81$. Apabila hutang naik 1 satuan maka nilai EPS naik sebesar 1,32 satuan, sedangkan apabila dividen naik 1 satuan maka EPS turun sebesar 0,52 satuan. Secara serempak hutang dan dividen secara signifikan berpengaruh terhadap nilai EPS. namun demikian secara individual hanya hutang secara signifikan yang berpengaruh terhadap nilai perusahaan.

\section{Saran}

Mengacu kepada hasil hal yang harus dilakukan oleh bank BNI adalah memperbesar hutangnya. Hutang akan memperbesar nilai perusahaan, 1 satuan kenaikan hutang akan menyebabkan kenaikan nilai perusahaan sebesar 1,32 satuan nilai perusahaan. Pada dasarnya hutang perusahaan akan disimpan dalam tabungan/simpanan masyarakat. Semakin besar simpanan masyarakat itu disalurkan dalam bentuk pinjaman maka akan semakin besar penghasilan yang diterima oleh bank BNI.

\section{DAFTAR PUSTAKA}

Brigham, Eugene F. dan Joel F. Houston. 2014.

Dasar-Dasar Manajemen Keuangan. Buku 1.Edisi 11.Jakarta : Salemba Empat.

Fabozzi, Frank J. and Peterson, Pamela P., 2003, Financial Management andAnalysis Scond Adition, John Wiley \& Sons, Inc., Hoboken, New Jersey

Farah Margaretha. 2004. Teori Dan Aplikasi Manajemen Keuangan Investasi dan Sumber DanaJangka Pendek. Jakarta. PT. Grasindo.

Harmono.(2017). Manajemen Kaungan Berbasis Balanced Scorecard Pendekatan Teori, Kasus, dan Riset Bisnis. Jakarta: Bumi Aksara.

Keown, Arthur J., Scott Jr., David F., Martin John D. and Petty J.William. 2001. Dasar-Dasar Manajemen Keuangan Jilid II. Jakarta : Salemba Empat.

Kumar, S., Anjum, B., and Nayyar, S. 2012. Financing Decisions : Studi of Pharmaceutical Companies of India. International Journal of Marketing, Financial Services \& Management Research, 1(1): pp : 14-28.

Martono dan Agus Harjito. 2013. Manajemen Keuangan. Yogyakarta : Ekonosia

Modigliani, F., \& Miller, M. H. (1958).The Cost of Capital, Corporation Finance and the Theory of Investment. The American 
Economic Review, 48(3), 261297.

Modigliani, F., \& Miller, M. H. (1963). Dividend Policy and Market Valuation: A Reply. The Journal of Business, 36(1), 116-119.

Myers, S. C. (2001). Capital Structures. The Journal of Economic Perspective, 15(2), 81-102.

Sutrisno.,2014.,Manajemen Keuangan Teori, Konsep dan Aplikasi,Ekonisia,Yogyakarta.

Weston, J. Fred dan Copeland, Thomas E.2001. Manajemen Keuangan Jilid 2. Edisi ke-9.Jakarta : Binarupa Aksara. 